\title{
ARTYKULY
}

\section{KWESTIA TZW. POWSTANIA KONSTANTYNA I FRUŻYNA W BUŁGARSKIEJ LITERATURZE NAUKOWEJ}

\author{
MirOSŁAW J. LESZKA
}

\begin{abstract}
Mirosław J. Leszka, Kwestia tzw. Powstania Konstantyna i Frużyna w bułgarskiej literaturze naukowej (The question of the so-called uprising of Konstantin and Fruzhin in Bulgarian scholarship).

The article demonstrates the main points made in the discussion on the co-called uprising of Konstantin and Fruzhin, raised in Bulgarian academic literature over the last one hundred fifty years.
\end{abstract}

SŁowA KLUCzowe: Konstantyn II Asen, Frużyn, carstwo widyńskie

KEYWORDS: Constantine II Asen, Fruzhin, Vidin Tsardom

Balcanica Posnaniensia. Acta et studia, XXI, Poznań 2014, Wydawnictwo Instytutu Historii UAM, pp. 5-12, ISBN 978-83-63047-59-7, ISSN 0239-4278. Polish text with a summary in English.

Mirosław J. Leszka, Uniwersytet Łódzki, Wydział Filozoficzno-Historyczny, Katedra Historii Bizancjum, ul. Kamińskiego 27 a, 90-219 Łódź, mirleszka@poczta.onet.pl.

Jednym z dość intensywnie dyskutowanych wątków dziejów bułgarskich z początków XV wieku jest tzw. powstanie Konstantyna i Frużyna, które ukazywane jest jako pierwsze antytureckie wystąpienie Bułgarów. Dyskusja jest trudna i daleka od jednoznacznych, powszechnie akceptowanych konkluzji. Żeby nie być gołosłownym nadmienię tylko, że nie wiemy, czy rzeczywiście na jego czele stali wzmiankowani Frużyn i Konstantyn, gdzie i kiedy wybuchło i jakie obszary objęło, jakie siły się w nie zaangażowały, kiedy się zakończyło ${ }^{1}$. Taki stan rzeczy jest przede wszystkim, co nie zaskakuje, konsekwencją stanu źródeł².

Celem niniejszego artykułu jest ukazanie w ogólnym zarysie głównych wątków dyskusji wokół tytułowej kwestii w bułgarskiej (głównie) literaturze naukowej w okresie ostatnich stu pięćdziesięciu lat.

Swoje rozważania rozpocznę od sumarycznego przedstawienia stanu naszej wiedzy na temat losów Konstantyna i Frużyna do początków XV w. Konstantyn II Asen ${ }^{3}$

\footnotetext{
${ }^{1}$ Na temat powstania najszerzej pisali: P. Petrov, Văstanieto na Konstantin i Fružin, „Izvestija na Instituta za Istorija” 1960, 9, s. 183-214; A. Kuzev, Vosstanie Konstantina i Fružina, „Bulgarian Historical Review” 1974, 2.3, s. 53-69. Inne najważniejsze prace, analizujące to wydarzenie, znajdzie Czytelnik w dalszej części niniejszego tekstu.

${ }^{2} \mathrm{Na}$ temat źródeł patrz poniżej.

${ }^{3} \mathrm{Na}$ temat losów Konstantyna podstawowe informacje - I. Božilov, Familijata na Asenevci (11861460). Genealogija i prosopografija, Sofija 1994, s. 237-240; P. Pavlov, Konstantin (Konstantin II Asen), w: J. Andreev, I. Lazarov, P. Pavlov, Koj koj e v srednovekovna Bălgarija, Sofija 2012, s. 381-385.
} 
był synem cara widyńskiego Jana Sracimira i księżniczki wołoskiej Anny. Urodził się prawdopodobnie w początkach lat siedemdziesiątych XIV w. Wiadomo, że ojciec proklamował go carem i ogłosił swoim współrządcą. Wiązano z nim duże nadzieje. Podkreślano jego mądrość i odwagę. W 1395 r. razem z Jozafatem (Joasaf), widyńskim metropolitą uczestniczył w poselstwie do Tyrnowa, znajdującego się już wówczas w rękach tureckich. Nie jest jasne, jaki był cel misji ${ }^{4}$. Jedynym znanym jej efektem było otrzymanie od tureckiego zarządcy Tyrnowa relikwii św. Filotei, które zostały przeniesione do Widynia. Dalsze losy Konstantyna są słabo znane. Część uczonych sądzi, że po opanowaniu Bułgarii widyńskiej przez Turków i wzięciu Jan Sracimira do niewoli, uniknął on losu tego ostatniego i poszedł na wygnanie. Niektórzy badacze uważają, że pozostał jednak w Widyniu. W źródłach pojawia się ponownie w roku 1404. W liście Zygmunta Luksemburczyka skierowanym do księcia burgundzkiego Filipa z 16 kwietnia tego roku określany jest mianem sławnego imperatora (cesarza / cara) Bułgarii 5 .

Frużyn ${ }^{6}$ był synem cara Jana Szyszmana, władcy tyrnowskiego, ale w najlepszym przypadku trzecim pod względem wieku (po Aleksandrze i Asenie). Jego matką była najprawdopodobniej Dragana, druga żona Jana, choć nie wyklucza się, że mógł on pochodzić z nieprawego łoża. Po 1395 roku opuścił zajęte przez Turków tereny Bułgarii tyrnowskiej. Być może udał się najpierw do Widynia, potem zaś na Węgry. Ta pierwsza destynacja jest jedynie hipotetyczna i nie ma potwierdzenia źródłowego, druga zaś znajduje uzasadnienie we wzmiance źródłowej pochodzącej dopiero z 1425/1426 r. Wtedy to Zygmunt Luksemburczyk nagrodził Frużyna nadaniem Lipy w komitacie Temesz (Fruschin filii quondam Susman imperatoris Bulgarorum) ${ }^{7}$. Natomiast nader wątpliwe jest doszukiwanie się potwierdzenia jego wcześniejszej obecności na Węgrzech w Żywocie Zygmunta Luksemburczyka Eberharda Windecke, niemieckiego autora z XV w., który wspomina, opisując wydarzenia z lat 1403-1406,

\footnotetext{
${ }^{4}$ Wiedza na temat tego poselstwa pochodzi jedynie z Mowy ku czci św. Filotei, autorstwa metropolity Jozafata - E. Kałužniacki, Aus der panegirischen Literatur der Südslaven, London 1971, s. 111-112. Na temat tego poselstwa i jego ewentualnych celów - P. Nikolov-Zikov, Dinastijata na Sracimirovci. Vlastovi doktrini i političeski modeli v jugoiztočna Evropa prez XIV vek, Sofija 2012, s. 137-138. O Mowie ku czci św. Filotei - K. Marinow, Problem zdobycia Tyrnowa przez Turków Osmańskich w literaturze naukowej oraz w świetle źródet pisanych i archeologicznych, Mars 17, 2004, s. 16; Istorija na bălgarskata srednovekovna literatura, red. A. Miltenova, Sofija 2008, s. 581-582. O zgromadzonych w Tyrnowie relikwiach świętych pisze m.in. K. Marinow, Inny Konstantynopol. Tyrnowo jako stoleczny ośrodek późnośredniowiecznej Bułgarii, w: Z badań nad wczesno bizantyńskim Konstantynopolem, red. M.J. Leszka, K. Marinow, A. Kompa, Łódź 2011 [= „Acta Universitatis Lodziensis.Folia Historica” 2011, 87], s. 350 352 (tam dalsza literatura). Być może w wyniku wzmiankowanego poselstwa do Widynia przewiezione zostały również relikwie św. Petki i św. Teofano.

${ }^{5}$ Tekst listu - M. Dinić, Pismo ungarskog krala Žigmunda Burgundskom vojvodi Filipu, „Zbornik za društvene nauke Matice srpske" 1956, 13/14, s. 96-97.

${ }^{6}$ Podstawowe wiadomości na temat losów Frużyna - I. Božilov, op. cit., s. 242-245; J. Andreev, P. Pavlov, Fružin (Fružin Asen), w: J. Andreev J. I. Lazarov, P. Pavlov, op. cit., s. 689-690.

${ }^{7}$ Codex diplomaticus Hungariae ecclesiasticus ac civilis, t. X, 6, ed. G. Fejér, Buda 1841, s. 784 785.
} 
wodza o imieniu Sussman ${ }^{8}$. Choć nie należy wątpić, co zabrzmi paradoksalnie, że Frużyn odegrał jakąś rolę w wydarzeniach pierwszej i drugiej dekady XV w., to jego imię się w nich w sposób bezpośredni nie pojawia.

\section{ŹRÓDŁA}

W przypadku tzw. powstania Konstantyna i Frużyna mamy do czynienia z wyjątkowo szczupłym materiałem źródłowym. Dysponujemy jedną, krótką wzmianką, którą można by uznać za bezpośrednio mówiącą o jakimś powstaniu na ziemiach bułgarskich. Przewodzili mu synowie carów bułgarskich, których jednak imiona się nie pojawiają. Wzmianka ta znajduje się w Żywocie Stefana Lazarevicia, który wyszedł spod pióra Konstantyna Kosteneckiego. Był on z pochodzenia Bułgarem, współczesnym wydarzeniom, do tego najprawdopodobniej mającym możliwość osobistego kontaktu z Konstantynem II Asenem, który życie swe zakończył 17 września 1422 roku w Belgradzie. Sam Żywot został napisany w latach 1431-1432 r. W inkryminowanym passusie znajdujemy informację o tym, że miasta bułgarskie zbuntowały się pod wodzą synów carów bułgarskich, w konsekwencji czego wystąpił car Muzułman i przybył do Temska, które zdobył ${ }^{9}$.

$\mathrm{Z}$ powstaniem łączy się i drugie źródło. Jest nim wzmiankowany już list Zygmunta Luksemburczyka do Filipa burgundzkiego, pochodzący z kwietnia roku 1404. Czytamy w nim:

...sławny pan Stefan, despota i duks Raszki, znany Konstantyn, sławny imperator Bułgarii (Constantinus, imperator Bulgariae magnificus) i Mircza, wojewoda Wołoszczyzny. Ostatni dwaj także wrócili pod nasze władanie, wiele razy napadali śmiało na greckie tereny i inne obszary, które dotąd znajdowały się we władaniu Turków, osiagnęli zwycięstwa nad wrogiem i sławę dla siebie ${ }^{10}$.

Źródło jest wiarygodne, pochodzi z epoki, natomiast ma jedna, ale wyjątkowo istotną wadę, mianowicie nie musi dotyczyć tej samej sytuacji, o której wspomina Konstantyn Kostenecki. O tym będę pisał w dalszym toku artykułu. Jeśli chodzi o inne źródła, które próbuje się wiązać z powstaniem, to obciążone są tą skazą jeszcze w większy sposób, a łączone są z nim lub odrzucane w zależności od tego jak postrzegali poszczególni autorzy zakres terytorialny działań powstańczych i czas ich trwania.

${ }^{8}$ E. Windecke, Das Leben Koenig Sigismunds, 19, ed. von Hagen, Leipzig 1899, s. 18. W Sussmanie upatrują Frużyna np. J. Andreev, P. Pavlov, op. cit., s. 690.

${ }^{9}$ V. Jagić, Konstantin Filosof i negov život Stefana Lazareviča despota srpskogo po dvjema srpsko-slovenskim rykopisima, „Glasnik srpskog učenog društva” 1875, 42, s. 292. Szerzej na temat Konstantyna Kosteneckiego patrz m.in. Ju. Trifonov, Život $i$ dejnost na Konstantin Kostenečki, „Spisanie na Bălgarskata akademija na naukite” 1943, 66, s. 223-285; G. Petkov, Konstantin Kostenečki, w: Kirilometodievska enciklopedija, t. II: J-O, red. P. Dinekov, Sofija 1995, s. 423-426; P. Pavlov, Konstantin Kostenečki, w: J. Andreev J. I. Lazarov, P. Pavlov, op. cit., s. 391-393. Pod określeniem „Muzułman” kryje się Sulejman.

${ }^{10}$ M. Dinić, Pismo, s. 96-97. 


\section{ROZWÓJ BADAŃ}

Punktem wyjścia do dyskusji o powstaniu stała się publikacja Konstantyna Jirečka ${ }^{11}$. Na podstawie przekazu Konstantyna Kosteneckiego sformułował on pogląd, że po bitwie pod Ankarą (1402) ok. 1405 r., wykorzystując osłabienie państwa tureckiego, zbuntowały się przeciw Turkom miasta bułgarskie wzdłuż granicy z Serbią, w dolinie Timoku. Za inicjatora tej akcji uznał on Konstantyna, syna Jana Sracimira, władcy widyńskiego. Ten ostatni, jak wiadomo, w jakiś czas po bitwie pod Nikopolem (1396) znalazł się w niewoli tureckiej, w której życie swe zakończył. Jireček uważał, że działania Konstantyna wsparł Frużyn, syn Jana Szyszmana, ostatniego cara Bułgarii tyrnowskiej. Bułgarskie wystapienie zostało szybko stłumione przez najstarszego z synów Bajezida I walczących o władzę w państwie osmańskim - Sulejmana.

Wystapienie Jirečka wywołało dyskusję. Wątpliwości odnoście niektórych jego ustaleń zgłosił serbski uczony Stojan Novaković ${ }^{12}$. Jego zdaniem do powstania doszło wiosną lub latem roku 1408 r. Także dla tej datacji podstawę stanowił przekaz Konstantyna Kosteneckiego. W Żywocie Stefana Lazarevicia informacja o bułgarskim powstaniu poprzedza bowiem datowany na rok 1409 podział serbskiej despotowiny między braci Lazareviciów (Vuka i Stefana). Powstanie, zdaniem Novakovicia rozpocząc się miało w górach między Serbią, Widyniem a Pirotem.

Wytyczonymi przez Jirečka i Novakovicia szlakami podążyli inni uczeni. I tak np. Wasył Zlatarski zaakceptował datację Jirečka ${ }^{13}$, a Jurij Trifonow ${ }^{14}$ Novakovicia. W 1928 r. Petar Nikov zaproponował inną datę ${ }^{15}$. Przyjął on, że powstanie rozegrało się w 1403 r. i objęło pograniczne ośrodki w okręgu Temska. Bułgarów, jego zdaniem, wspierali Serbowie. Sulejman jednym uderzeniem stłumił powstanie.

Nowy impuls do dyskusji o powstaniu wprowadził w 1956 r. Mihajlo Dinićc ${ }^{16}$. Wydał on pełny tekst listu Zygmunta Luksemburczyka do Filipa, burgundzkiego, który zachował się w pochodzącej z początków XV w. kronice Jeana Brandona. List wystosowany został, jak to już wzmiankowano, 16 kwietnia roku 1404, a mowa w nim jest m.in. o sławnym bułgarskim imperatorze Konstantynie, jako uczestniku antytureckiej koalicji. Dinić doszedł do wniosku, że list należy traktować, jako kolejne źródło mówiące o powstaniu Konstantyna i Frużyna, stąd jego propozycja, by powstanie datować najpóźniej na początek roku 1404.

${ }^{11}$ K. Jireček, Bălgarskijat car Sracimir Vidinski, ,Periodičesko spisanie” 1882, 2. 1, s. 52-53.

12 S. Novaković, Srbi i turci XIV i XV veka, Beograd 1892, s. 324-328.

${ }^{13}$ V. Zlatarski, Nova političska i socjalna istorija na Bălgarija i Balkanskija poluostrov, Sofija 1921, s. 1.

14 Ju. Trifonov, Beležki vărchu razvitieto na pesnite za Novaka u bălgarite i sărbite, „Spisanie na Bălgarskata akademija na naukite" 1923, 29, 16, s. 124.

15 P. Nikov, Turskoto zavladjavane na Bălgarija i sădbata na poslednite Šišmanovci, „Izvestija na Istoričeskoto družestvo v Sofija" 1928, 7/8, s. 93.

${ }^{16}$ M. Dinić, op. cit., s. 96. 
W cztery lata później ukazał się obszerny artykuł Petyra Petrowa ${ }^{17}$, który dokonał ponownej analizy źródeł i zbudował nowy obraz powstania. Jego zdaniem bułgarskie powstanie było częścią powstałej po bitwie pod Ankarą antytureckiej koalicji pod przywództwem Węgier, w której znajdowali się Bułgarzy i Wołosi. Według niego Konstantyn II Asen po zajęciu Bułgarii widyńskiej przez Turków znalazł schronienie na Wołoszczyźnie i działał przeciw Turkom za zgodą i w sojuszu z Mirczą Starym, władcą wołoskim. Według bułgarskiego uczonego powstanie wybuchło na terenach byłego państwa widyńskiego, a działania wojenne toczyły się na szerokim froncie wzdłuż Dunaju. Konstantyn był przywódcą i organizatorem powstania, a Frużyn, żyjący na Węgrzech, przyszedł mu na pomoc z wysłanym przez Zygmunta węgierskimi wojskami. Powstanie objęło dzisiejszą półn.-zach. Bułgarię (okręg widyński, michałowogodzki, wraczański), dolinę rzeki Morawy, okręg Pirotu, Niszu, a może i Sofii) i trwało od stycznia do maja / czerwca $1404 \mathrm{r}$.

Poglądy Petrowa spotkały się z krytyką Genowewy Cankowej-Petkowej, szczególnie w kwestii rozległości terenów, na których prowadzone miały być działania powstańcze. Uważała ona również, że Mircza Stary, hospodar wołoski nie wspierał powstania. Co do datacji, to umieściła powstanie w marcu roku $1404^{18}$.

Ważny głos w dyskusji zajął w 1974 r. Aleksandr Kuzew. Zanegował on traktowanie listu Zygmunta Luksemburczyka, jako źródła mówiącego o powstaniu Frużyna i Konstantyna. Kuzew zwrócił uwagę na fakt, że uczestnicy wzmiankowanej w liście koalicji osiagnęli sukcesy w walkach z Turkami (Serbowie zdobyli twierdze, Wołosi Dobrudżę i Dorostolon), a Konstantyn Kostenecki pisał o pokonaniu przez Turków bułgarskich buntowników w Temska. Po wtóre, jeśli wyprawy Konstantyna II Asena na tereny bułgarskie pod panowaniem tureckim były wspierane przez zbuntowane miasta, to dlaczego trzeba było je powtarzać? Kuzew powstrzymał się od narzucającego się pytania: dlaczego nie ma mowy w liście Zygmunta Luksemburczyka o Frużynie i powstaniu bułgarskich miast. Z Żywotu Stefana Lazarevicia, dowodził Kuzew, wynika, że w czasie powstania bułgarskich miast nie toczyła się wojna między Serbami i Turkami, ponieważ Sulejman dwukrotnie zwracał się z prośbą do serbskiego władcy. Bezpośrednio przed tą wzmianką Sulejman prosił o zlikwidowanie jakiegoś rozbójnika sprawiającego Turkom kłopoty, a po tej wzmiance pojawia się informacja o prośbie Sulejmana o zgodę na przejście przez serbskie ziemie. Tutaj Kostenecki podkreśla, że ziemia nie była jeszcze rozdzielona pomiędzy Stefana i jego brata Vuka, co nastapiło w czerwcu roku 1409. W Serbii po drodze do Owczego Pola na Sulejmana napadł Karaljuk, wspomniany wyżej rozbójnik, który przekazał zdobycz Stefanowi, a ten zwrócił łupy Sulejmanowi.

A. Kuzew, odrzucając list Zygmunta, jako źródło do powstania, przyjął za punkt wyjścia do datowania tego wydarzenia przekaz Kosteneckiego. Konsekwencją tego było przyjęcie daty rozpoczęcia powstania proponowanej jeszcze przez Novakovicia,

\footnotetext{
${ }^{17}$ P. Petrov, op. cit.

${ }^{18}$ Swoje poglądy przedstawiła G. Cankowa-Petkowa w recenzji tekstu Petrowa - „Istoriceski Pregled" 1962, 18, s. 92-98.
} 
a więc roku 1408. Według niego powstanie objęło tak wschodnią, jak i zachodnią część Bułgarii tyrnowskiej. Bułgarzy mogli liczyć jedynie na pomoc Wołochów, którzy byli wrogo nastawieni do Sulejmana i udzielali pomocy każdej akcji skierowanej przeciw niemu. Frużyn dowodził powstaniem we wschodniej Bułgarii- W widyńskiej Bułgarii powstańczymi działaniami kierował Konstantyn. Prawdopodobnie przybył z Serbii, od której uzyskał wsparcie. Powstanie według Kuzewa zostało stłumione dopiero 23 kwietnia roku 1413 i to nie przez Sulejmana a przez Musę.

Wystąpienie Kuzewa zakończyło na pewien czas dyskusję wokół powstania. Uczeni, którzy później z jakichś powodów nawiązywali do tego wydarzenia opowiadali się za propozycją Petrowa względnie Kuzewa.

Nowe wątki do dyskusji wprowadzili w latach 90. XX dwaj uczeni związani z Uniwersytem Tyrnowskim, a mianowicie Iwan Tjutjundżiew i Płamen Pawłow ${ }^{19}$. Przedmiotem ich badań nie tyle były losy powstania, co dzieje Bułgarii widyńskiej po usunięciu Jana Sracimira. Jak powszechnie wiadomo w nauce funkcjonował i nadal funkcjonuje pogląd, zgodnie z którym po zwycięskiej dla Turków bitwie pod Nikopolem (1396) Bułgaria widyńska została włączona w skład państwa tureckiego.

Według tych autorów można wskazać w źródłach z końca XIV i początków XV w. passusy świadczące o tym, że nazwa Bułgaria funkcjonowała nadal jako pojęcie państwowo-polityczne. Na pierwszy plan wysunęli oni wzmiankowany już kilkukrotnie list Zygmunta Luksemburczyka do Filipa burgundzkiego, w którym wymienieni są walczący przeciw Turkom węgierscy wasale, a mianowicie król Bośni, władca Raszki, Konstantyn, imperator Bułgarii i Mircza, wojewoda Wołoszczyzny ${ }^{20}$. Bułgarscy autorzy zwrócili uwagę, że Zygmunt Luksemburczyk umieścił Konstantyna wśród bałkańskich władców, którzy sprawowali rzeczywistą władzę. Król węgierski z niejaką dumą donosi Filipowi, że imperator Bulgariae i wojewoda wołoski wrócili pod jego zwierzchność. Oznacza to zapewne, że wcześniej władca Bułgarii uznawał zwierzchność turecką. Inne źródło, przywoływane przez bułgarskich uczonych, to postanowienia Wielkiej Rady Republiki Dubrownickiej z 28 listopada 1398 o pełnomocnictwach konsulów in partibus Sclavoniae, Bossine, Sriemie et Bulgarie [podkreśl. M.J.L.]. $\mathrm{Z}$ kolei w postanowieniu pochodzącym z 23 marca 1411 r. informuje się o śmierci kupca Jakszy Pribilovicia in le parte di Bulgaria (bułgarski kraj lub bułgarskie państwo $)^{21}$. W gramocie Stefana Lazarevicia z 1406 r. dla monasterów na Wołoszczyźnie (Tismana i Vodița) mowa jest o węgierskiej i bułgarskiej ziemi²2.

19 P. Pavlov, I. Tjutjundžiev, Osmanskite turci i krajat na srednovekovna Bălgarija, Veliko Tărnovo 1991; iidem, Bălgarite i osmanskoto zavoevanie (za krajat na XIII-sredata na XV v.), Veliko Tărnovo 1995, s. 88-96; 114-131. Poglądy wyrażone w powyższych pozycjach powtórzył niedawno P. Pawłow w artykule Car Konstantin II Asen (1397-1422) i krajat na srednovekovnata bălgarska dăržavnost, w: idem, Bălgarskoto srednovekovije. Poznato i nepoznato. Stranici ot političeskata i kulturnata istorija na Bălgarija, VII-XV vek, Veliko Tărnovo 2008, s. 209-229.

20 P. Pavlov, I. Tjutjundżiev, Balgarite i osmanskoto..., s. 115.

21 Ibidem, s. 116.

22 Ibidem, s. 117. 
Powyższe świadectwa źródłowe prowadzą Pawłowa i Tjutjundżiewa do wniosku, że Bułgaria widyńska po usunięciu Jana Sracimira została przekazana jego synowi Konstantynowi, który musiał uznać zwierzchność Bajazyda. Potwierdzenie tej konstatacji znajdują bułgarscy uczeni w Ruskim chronografie, który donosi, że widyńskie carstwo otrzymało w $1397 \mathrm{r}$. status podobny do arbańskich (albańskich) i bośniackich władcó $^{23}$, jak i u wołoskiego kronikarza Mihaia Moxy, który pod rokiem 6906 (1 września 1397-31 sierpnia 1398) informuje, że Jan Sracimir został wasalem sułtana (tu popełnił błąd, bo zapewne chodziło o Konstantyna) ${ }^{24}$.

Według Pawłowa i Tjutjundżiewa po klęsce Turków pod Ankarą w 1402 r. Konstantyn - podobnie jak inni władcy bałkańscy - zerwał zależność od Turków i włączył się do organizowanej przez Zygmunta Luksemburczyka koalicji ${ }^{25}$.

Pawłow i Tjutjundżiew akceptują wnioski Kuzewa, co do wybuchu powstania wskazując, że doszło do niego w Bułgarii Tyrnowskiej przy wsparciu Konstantyna władcy widyńskiego. W kontekście ich rozważań należałoby jednak mówić, jak sądzę, nie tyle o powstaniu Konstantyna i Frużyna, co raczej o działaniach tego pierwszego na rzecz rozszerzenia i umocnienia rządzonego przez siebie organizmu państwowego, w których ewentualnie wsparł go ten ostatni, podejmując wrogie Turkom kroki na części opanowanego przez nich terytorium Bułgarii tyrnowskiej.

Wspomniani tyrnowscy badacze, co znamienne, wskazuja, że po $1413 \mathrm{r}$. Konstantyn zachował, jako sojusznik, Mehmeda pewną niezależność, na znajdującym się pod jego władzą terytorium. Jej kres przyniosła dopiero śmierć bułgarskiego cara, która nastapiła, jak już wspomniałem, w 1422 r. I dopiero wtedy, zdaniem Pawłowa i Tjutjundżiewa, nastąił koniec średniowiecznej państwowości bułgarskiej ${ }^{26}$.

Poglądy Płamena Pawłowa i Iwana Tjutjundżiewa, choć nie zostały zaakceptowane przez znaczną część bułgarskich uczonych (co nie oznacza, że poddano je jakiejś gruntownej krytyce ${ }^{27}$ ), to każą spojrzeć przynajmniej z dozą nieufności na utrwalony w literaturze naukowej obraz dziejów ziem bułgarskich od połowy lat dziewięćdziesiątych XIV w. po początki lat dwudziestych wieku XV.

W ostatnim czasie hipotezę Pawłowa i Tjutjundżiewa promuje, i w pewnym stopniu rozwija Petyr Nikołow-Zikow ${ }^{28}$. Uznaje on funkcjonowanie po 1396 r. - w jakimś stopniu niezależnego od Turków - państwa bułgarskiego z centrum w Widyniu, czego logicznym następstwem jest stwierdzenie, że nie było czegoś takiego jak powstanie Konstantyna i Frużyna i że jest ono produktem współczesnych badaczy ${ }^{29}$. Dla

23 Ibidem, s. 120.

24 Ibidem

25 Ibidem, s. 121.

26 Ibidem, s. 125.

27 Sytuację ignorowania poglądów tyrnowskich uczonych i niepoddawania ich naukowej krytyce z pewnym żalem odnotował kilka lat temu Płamen Pawłow (Car Konstantin II Asen (1397-1422) i krajat..., s. 209).

28 P. Nikolov-Zikov, Dinastijata na Sracimirovci..., s. 140-148; idem, Istinskata istorija na vidinskoto knjažestvo, Sofija 2014, s. 125-141.

29 P. Nikolov-Zikov, Istinskata istorija..., s. 132. 
równowagi Christo Matanow, wybitny znawca historii średniowiecznych Bałkanów, w opublikowanej w tym roku książce pisze o pierwszym antytureckim powstaniu na czele z Konstantynem i Frużynem i w ogóle nie odnosi się do poglądów Pawłowa, Tjutjundżiewa i Nikołowa-Zikowa ${ }^{30}$.

Powyższy, z natury rzeczy, dość pobieżny przegląd stanowisk funkcjonujących w bułgarskiej literaturze naukowej w sprawie tzw. powstania Konstantyna i Frużyna, a szczególnie drastyczny niekiedy rozdźwięk między poglądami poszczególnych uczonych (od wskazywania na jego epizodyczność, krótkotrwałość i niewielki zasięg terytorialny, przez ukazywanie go jako długoletnich zmagań, obejmujących znaczne połacie Bułgarii widyńskiej i tyrnowskiej, po uznanie go za wymysł nowożytnych uczonych) prowadzić musi do wniosku, że istnieje potrzeba przyjrzenia się jej raz jeszcze i w efekcie czego zbudowania bardziej wyważonego, silniej wpisanego w ogólnobałkańską sytuację i uwzględniającego różne nurty naukowej dyskusji obrazu dziejów ziem bułgarskich w pierwszych dwudziestu pięciu latach po bitwie nikopolskiej.

\title{
THE QUESTION OF THE SO-CALLED UPRISING OF KONSTANTIN AND FRUZHIN IN BULGARIAN
}

\author{
MirosŁaW J. LESZKA
}

Summary

The present article demonstrates the main points made in the discussion on the co-called uprising of Konstantin and Fruzhin, raised in Bulgarian academic literature over the last one hundred fifty years. The overview of the proposed approaches (which concern, amongst other, such issues as when and where the rebellion broke out, how large forces where involved in it and when it came to an end) leads the author of the study to the conclusion that there is an urgent need for the academic world to develop (balanced and more closely connected with the results of the academic discussion) a vision not only of the topical issue itself but also of the whole first quarter of the century after the battle of Nicopolis.

${ }^{30} \mathrm{Ch}$. Matanov, V tărsene na srednovekovnoto vreme. Neravnijat păt na bălgarite (VII-XV v.), Sofija 2014, s. 451. 